sufficient effort, releases of radioactivity to man's environment can be reduced to zero. In its simplest form, this view was expressed as an outright condemnation of any discharges of radioactivity to the sea, or to other parts of man's environment. The weakness of the position adopted by the supporters of this view is in the absolute nature of their claim. Some quantities of radioactivity are demonstrably trivial in any environment, and a complete denial of this can have only one practicable meaning - that no use can be made of radioactive materials or nuclear power. Clearly the supporters of this absolute point of view are not anxious to achieve the banning of artificial radioactivity and nuclear power ; their aim is presumably that of all the specialists in this field, namely, to deal with radioactive waste in ways which do not harm man or spoil his environment. By refusing to admit the possibility of agreeing either on scientifically based standerds or on legel provisions controlling the disposal of waste at sea, they are actually reducing the chances of achieving this aim.

It would be wrong to under-estimate the importance of these differences of opinion, and we shall certainly hear more of them in future conferences on atomic energy and on such things as the law of the sea. On the other hand, they were by no means a dominant feature of the Monaco Conference, which should be remembered more for the opportunities it gave for exchanging views. There was complete agreement that nuclear power must not be allowed to impair man's use of the resources of the sea, either now or in the future, but as one prominent oceanographer remarked-the ability to receive wastes without damage is one of the resources of the sea. If an appropriate balance is to be obtained between the utilization of marine resources and the cost to mankind of nuclear power, the oceanographers and marine biologists must join the chemists and chemical engineers in quantitative studies aimed at providing governments with the scientific basis of a balanced decision.

\section{BIOLOGICAL CONCEPTS BEFORE DARWIN}

Forerunners of Darwin

1745-1859. Edited by Bentley Glass, Oswei Temkin and William L. Straus, Jr. Pp. viii +471 . (Baltimore, Md.: The Johns Hopkins Press ; London : Oxford University Press, 1959.) 52s. net.

W ${ }^{H E N}$ a man has done many things he is more likely to have had numerous forerunners than if he had done nothing, and their number is no disparagement to his achievement, as can be seen in the case of Darwin. This is all the more so when the forerunners are selected from only a part of his fields of activity, represented by evolution by natural selection and omitting his work on coral reefs, volcanic islands, insectivorous plants, climbing plants, crossfertilization, and methods of communication between animals by means of the expression of the emotions. The forerunners in the field of transmutation of species and the methods by which it has been brought about are by themselves quite sufficient to fill a splendid volume.

From a recently discovered letter addressed by Darwin to Baden Powell, the contribution which Darwin claimed as his own unaided achievement is now precisely known. It is to have discovered the explanation of "how species become modified, \& to a certain extent how the theory of descent explains certain large classes of facts", in which respect he received no assistance from his predecessors. As more and more manuscripts come to light, and exist. ing documents are studied more critically, the number of forerunners in any field increases. With the help of hindsight, as Prof. Loren C. Eiseley has shown, it is possible to read into some works certain ideas which, in fact, their authors did not consciously recognize. He has established a criterion which must be satisfied before a forerunner of Darwin can be accepted as a real precursor. There must be recognition of the similarity between artificial and natural selection, and the conception of unlimited organio change in vast periods of time. Played according to these rules, the exploration of biological concepts prior to Darwin is a fascinating game to which the book under review is a perfect guide. Its fifteen chapters are as many essays on various aspects of the theory by a number of recognized experts, and the fact that some points here and there will lead to disagreement on matters of detail only shows how stimulating and thought-provoking the book is.

Gavin de Brer

\section{PEDOLOGY}

Fundamentals of Soil Science

By Prof. C. E. Millar, L. M. Turk and Prof. H. D Foth. Third edition. Pp. $x+526$. (New York: John Wiley and Sons, Ine.; London : Chapman and Hall, Ltd., 1958.) 62s, net.

Introduction to Soil Science

By Prof. G. W. Leeper. Third edition. Pp. viii + $222+12$ plates. (Carlton: Melbourne University Press ; London : Cambridge University Press, 1957.) 30s. net.

The Study of the Soil in the Field

By G. R. Clarke. Fourth edition. Pp. $204+6$ plates. (Oxford: Clarendon Press; London: Oxford University Press, 1957.) 35s. net.

LTHOUGH pedology has now advanced to the A point where it has become a coherent discipline worthy to be taught as a subject in its own right at university-level, it has for too long been regarded simply as a branch of husbandry, taught in agricul. tural faculties for agricultural ends. One result of this is the present lack of adequately trained pedologists ; another is the virtual absence of good up-to-date text-books which develop the whole subject in a balanced and logical fashion. Unfortunately, neither of the two general text-books under review does anything to rectify this situation.

"Eundamentals of Soil Science" in no way lives up to its title. It is a superficial descriptive text, adequate, perhaps, for potential farmers familiar with North American conditions but quite unsuitable as the university text-book which it claims to be, for two main reasons.

In the first place, it fails to take advantage of the results of modern work (for example, on the structures 